Aquaculture

Volume 49, Issue 3-4, 1 November 1985, Pages 231-244

\title{
Mass culture and biochemical variability of the marine microalga Tetraselmis suecica Kylin (Butch) with high nutrient concentrations
}

Fabregas, J., Herrero, C., Cabezas, B., Abalde, J.

Departamento de Microbiología, Facultades de Farmacia y Medicina, Universidad de Santiago de Compostela, Spain

Fabregas J, Herrero C, Cabezas B, Abalde J. Mass culture and biochemical variability of the marine microalga Tetraselmis suecica Kylin (Butch) with high nutrient concentrations. Aquaculture 1985;49(3-4):231-244.

ISSN: 00448486

DOI: 10.1016/0044-8486(85)90082-1

\begin{abstract}
Mass cultures of Tetraselmis suecica were carried out with four nutrient concentrations, ranging from 2 to $16 \mathrm{mM}$ of $\mathrm{NaNO}_{3}$ and salinity $35 \%$. An air flow of $15 \mathrm{l} / \mathrm{min}$ maintained a $\mathrm{CO}_{2}$ transference rate sufficient to keep the $\mathrm{pH}$ below 8.4. Using these cultural conditions equations were calculated, by a multiple non-linear least squares regression of order four, enabling predictions to be made of growth kinetics and chemical composition. Maximum cellular densities of $7.83 \times 10^{6}$ and $7.15 \times 10^{6}$ cells $/ \mathrm{ml}$ were obtained with 8 and $16 \mathrm{mM}$ of $\mathrm{NaNO}_{3}$, respectively. Growth velocity ranged between 0.53 and 0.63 doublings (dbl)/day, although $0.98 \mathrm{dbl} /$ day were reached with $16 \mathrm{mM}$ of $\mathrm{NaNO}_{3}$. Volume increased with nutrient concentration from 252 to $905 \mu^{3}$. Protein content reached maximum values of $306 \mu \mathrm{g} / \mathrm{ml}$ or $59.8 \mathrm{pg} / \mathrm{cell}$. In the logarithmic phase, protein was regulated by nutrient concentration and decreased according to this concentration. Maximum efficiency of transformation from nitrate to protein was $108 \%$, obtained at $2 \mathrm{mM}$ of $\mathrm{NaNO}_{3}$. Efficiency decreased, to $14 \%$, when nutrient concentration increased. This fact indicates that the lowest cost of harvesting is obtained with a nutrient concentration of $2 \mathrm{mM} \mathrm{NaNO}_{3}$. Chlorophyll a cell reached values
\end{abstract}


between 3.1 and $3.8 \mathrm{pg} / \mathrm{cell}$ in the stationary phase. There was a relationship between nutrient concentration and chlorophyll $\alpha$ cell in the logarithmic phase, with an increase from $2.15 \mathrm{pg} / \mathrm{cell}$ to $3.74 \mathrm{pg} / \mathrm{cell}$. Changes in chlorophyll a level are related to nitrogen depletion. Carbohydrate/cell was constant at values of 19.84-28.68 pg/cell in the logarithmic and stationary phases and was not related to nitrogen depletion. RNA/cell ranged from 4.17 to $5.48 \mathrm{pg} / \mathrm{cell}$, except at $2 \mathrm{mM}$ of $\mathrm{NaNO}_{3}$ when it was $2.77 \mathrm{pg} / \mathrm{cell}$, probably due to nitrogen depletion. The level of DNA/cell was constant in all the nutrient concentrations assayed and ranged from 0.1 to $1.09 \mathrm{pg} / \mathrm{cell}$. Great variability in the chemical composition of T. suecica has been shown. Growth in mass cultures is closely coupled to changes in nutrient concentrations and variations occur in protein, chlorophyll $\alpha$ and RNA content, showing differences of $215 \%, 190 \%$ and $203 \%$, respectively, in the stationary phase. This biochemical variability, mainly in protein content, must have a marked effect on the nutritive value of this microalga as feed in mariculture.

\section{Introduction}

Microorganisms are potentially useful in aquaculture, in the bioconversion of solar energy, in the production of chemicals and as food for human consumption (Kharatyan, 1978; Goldman, 1979). The marine micro alga Tetraselmis suecica Kylin (Butch) is at present widely used in aquaculture (Walne, 1974; Bayne, 1976; Laing and Utting, 1980). Knowing its ability to grow in a wide range of nutrient concentrations and salinity conditions, in batch cultures, we have previously established some of the parameters for mass production and this has enabled us to obtain maximum growth velocity and cellular density and we have also been made aware of its biochemical variability (Fabregas et al., 1984a). Our experience with laboratory mass cultures may, therefore, enable us to establish some of these parameters for outdoor mass cultures.

We report here the response of a mass culture of Tetraselmis suecica to a series of high nutrient concentrations. The work was done in order to establish the conditions for maximum production, to predict the response of the organism and to estimate its biochemical variability, since this variability can affect its nutritive value when this species is used as feed in mariculture.

\section{Materials and methods}

Tetraselmis suecica Kylin (Butch), the marine microalga used here, was isolated from Ria de Arosa waters (NW of Spain). It was cultured in seawater which had been filtered through a 
$0.45 \mu M$ Millipore filter, autoclaved at $120^{\circ} \mathrm{C}$ for $60 \mathrm{~min}$ and enriched with $\mathrm{NaNO}_{3}, 2 \mathrm{mM}$; $\mathrm{NaH}_{2} \mathrm{PO}_{4}, 100 \mu M ; \mathrm{ZnCl}_{2}, 1 \mu M ; \mathrm{ZnCl}_{2}, 1 \mu M ; \mathrm{Na}_{2} \mathrm{MoO}_{4}, 1 \mu M ; \mathrm{CoCl}_{3}, 0.1 \mu M ; \mathrm{CuSO}_{4}, 0.1$ $\mu M$; ferric citrate, $20 \mathrm{MM}$; thiamine, $35 \mu \mathrm{g} / \mathrm{l}$; biotin, $5 \mu \mathrm{g} / \mathrm{l}$; B 12, $3 \mathrm{J.Lg} / \mathrm{l}$; EDTA,26.4 $\mu \mathrm{M}$; Tris$\mathrm{HCl}, 5 \mathrm{mM}$. Salinity of the seawater was $35 \%$ and the initial $\mathrm{pH}$ of the cultures was 7.6.

The nutrient solution with the composition given above, containing $\left.\mathrm{NaNO}_{3}\right) 2 \mathrm{mM}$, was the first to be used. From this we followed a geometrical progression, using concentrations corresponding to 4,8 and $16 \mathrm{mM}$ of $\mathrm{NaNO}_{3}$. Nutrient concentrations are expressed as $\mathrm{NaNO}_{3}$ concentrations, but all the other nutrients were proportionally increased.

Cultures were contained in 10-I flasks with $9 \mathrm{I}$ of culture medium. All cultures were maintained in a controlled environment incubator at $15 \pm 1^{\circ} \mathrm{C}$ and illuminated with 11 fluorescent lamps (Osram daylight L55/10), five of which were placed under the flasks and six alongside them. A light:dark regime of $12 \mathrm{~h}: 12 \mathrm{~h}$ was maintained in order to obtain synchronous cultures. An inoculum of $50 \times 10^{4}$ logarithmic phase cells $/ \mathrm{ml}$ was used. Cultures had air continuously bubbled through them at a rate of $15 \mathrm{l} / \mathrm{min}$.

Cellular density was determined by counting culture aliquots in a Thoma chamber.

Cell volume was calculated by measuring the width and length of a significant number of cells under the microscope, and assuming the cell to be cylindrical.

Chlorophylls were extracted in acetone-methanol $2: 1$ at $4^{\circ} \mathrm{C}$ for $48 \mathrm{~h}$. The extracts were filtered through a Fluoropore Millipore filter for clarification (Fabregas et al., 1984b), and the absorbance of the pigment extract at specific wavelengths was recorded. The concentration of chlorophyll a was determined by the following formula (Parsons and Strickland, 1965): chlorophyll $\alpha(\mathrm{mg} / \mathrm{I})=11.64 \times D_{663}-2.16 \times D_{645}-0.1 \times D_{630}(\mathrm{U} / \mathrm{V})$, where $D_{630}, D_{645}$ and $D_{663}$ are the absorbances at 630,645 and $663 \mathrm{~nm}$ respectively, read in a $1.0 \mathrm{~cm}$ cell; $V$ is the sample volume, and $U$ is the final acetone-methanol volume.

Protein and carbohydrates were measured in the crude extracts obtained after collecting the microalgal cells by centrifugation, resuspending them in distilled water and breaking them in an ultrasonic disintegrator. After sonication the extracts were centrifuged again, the pellets were discarded and protein and carbohydrates were measured in the supernatants. Protein was measured by the dye-binding method (Bradford, 1976) and carbohydrates by the phenol-sulphuric acid method (Kochert, 1978a).

Nucleic acids were extracted with perchloric acid, and ribonucleic acid (RNA) and deoxyribonucleic acid (DNA) were determined as described by Kochert (1978b). 
Stationary phases were compared by an overall multivariate one-way analysis of variance (ANOVA) and logarithmic phases were compared by a one-way analysis of co variance (ANCOV A).

A multiple non-linear least squares regression of order 4 was applied to all the curves. The resultant equations were as follows:

$$
f(t)=a+b t+c t^{2}+d t^{3}+e t^{4}
$$

where $t(t)$ is cellular density or proteins $/ \mathrm{ml}$ or carbohydrates $/ \mathrm{ml}$ or chlorophyll $\alpha / \mathrm{ml}, t$ is time in days, and $a, b, e . d$ and $e$ are the coefficients of the equation.

From the growth equation we calculated doublings/day :

$$
\mathrm{dbls} / \mathrm{day}=t_{\mathrm{d}}^{-1}=\frac{\ln f\left(t_{n}\right)-\ln f\left(t_{\mathrm{i}}\right)}{\ln 2\left(t_{n}-t_{\mathrm{i}}\right)}
$$

where $t j$ and $t n$ are the initial and final time of the logarithmic phase, both expressed in days, and td is the duplication time.

\section{Results and discussion}

The Prasinophyte Tetraselmis sueciea is one of the microalgae being increasingly used in aquaculture. Mass culture of the organism and improved knowledge of its composition, growth and chemical variability will enable its better use in marine aquaculture.

TABLE 1

Statistical analysis of the growth curves of $T$. suecica at different nutrient concentrations in mass culture. Each value corresponding

\begin{tabular}{|c|c|c|c|c|c|c|c|c|c|}
\hline & \multirow[t]{2}{*}{ Growth phase } & \multirow[t]{2}{*}{$P$} & \multicolumn{7}{|c|}{ Nutrient concentration $^{\mathbf{a}}$} \\
\hline & & & $2 \mathrm{mM}$ & & $4 \mathrm{mM}$ & & $8 \mathrm{mM}$ & & $16 \mathrm{mM}$ \\
\hline $\begin{array}{l}\text { Cell } / \mathrm{ml} \times 10^{4} \\
\text { Time interval, days }\end{array}$ & Stationary ${ }^{\mathbf{b}}$ & 0.01 & $476 \pm 20$ & $=$ & $511 \pm 41$ & $<$ & $783 \pm 45$ & $=$ & $715 \pm 34$ \\
\hline $\begin{array}{l}\left(t_{n}-t_{\mathrm{i}}\right) \\
\text { Doublings/day } \\
\text { Protein }\end{array}$ & Logarithmic $^{c}$ & 0.01 & $\begin{array}{l}6-3 \\
0.63\end{array}$ & $=$ & $\begin{array}{l}6-2 \\
0.55\end{array}$ & $=$ & $\begin{array}{l}5-3 \\
0.53\end{array}$ & $<$ & $\begin{array}{l}5-2 \\
0.98\end{array}$ \\
\hline $\begin{array}{l}(\mu \mathrm{g} / \mathrm{ml}) \\
\text { Chlorophyll } a\end{array}$ & Stationary & 0.01 & $190 \pm 23.6$ & $<$ & $306 \pm 27$ & $>$ & $247 \pm 24$ & $>$ & $196 \pm 9.1$ \\
\hline $\begin{array}{l}(\mu \mathrm{g} / \mathrm{ml}) \\
\text { Carbohydrates }\end{array}$ & Stationary & 0.01 & $9.9 \pm 1.2$ & $<$ & $19.2 \pm 2.8$ & $=$ & $21.9 \pm 1.9$ & $=$ & $23 \pm 1.9$ \\
\hline$(\mu \mathrm{g} / \mathrm{ml})$ & Stationary & 0.01 & $130 \pm 12$ & $=$ & $111.5 \pm 3.11$ & $<$ & $193 \pm 6.2$ & $=$ & $173 \pm 8.2$ \\
\hline $\begin{array}{l}\text { Volume }\left(\mu \mathrm{m}^{3}\right) \\
\text { Efficiency }\end{array}$ & $\begin{array}{l}\text { Stationary } \\
\text { Stationary }\end{array}$ & 0.05 & $\begin{array}{l}252 \pm 59 \\
108\end{array}$ & $<$ & $\underset{87.5}{753} \pm 64$ & $<$ & $\begin{array}{l}848 \pm 51 \\
27.5\end{array}$ & $<$ & $\begin{array}{l}905 \pm 62 \\
14\end{array}$ \\
\hline
\end{tabular}
to a nutrient concentration is compared only with the succeeding concentration

axpressed as $\mathrm{NaNO}_{3}$ concentration.

${ }^{b}$ One-way analysis of variance (ANOVA).

${ }^{c}$ One-way analysis of covariance (ANCOVA).

Cultural conditions were established in order to obtain a maximum biomass production and to ensure that light, $\mathrm{pH}$ and carbon source did not become limiting. Cultures were, therefore, illuminated with a sufficient number of fluorescent lamps (11) so that light did not become 
limiting due to the high cellular densities obtained. It has been shown that there was little increase in the yields when illumination was provided by 6 to 8 lamps (Laing and Helm, 1981).

The growth of $T$. suecica generated a strong alkalinity in the cultures since the uptake of $\mathrm{NaNO}_{3}$ during photosynthesis generates alkalinity (Goldman et al., 1972; Brewer and Goldman, 1976). In our growing system, at low $\mathrm{CO}_{2}$ concentrations $(0.03 \% v / v$, in the air), an air flow of $15 \mathrm{l} / \mathrm{min}$ maintained a transference of $\mathrm{CO}_{2}$ to the culture medium that kept the $\mathrm{pH}$ below 8.4 (Fig. 1). In addition, these culture conditions ensured that the carbon source did not become limiting.

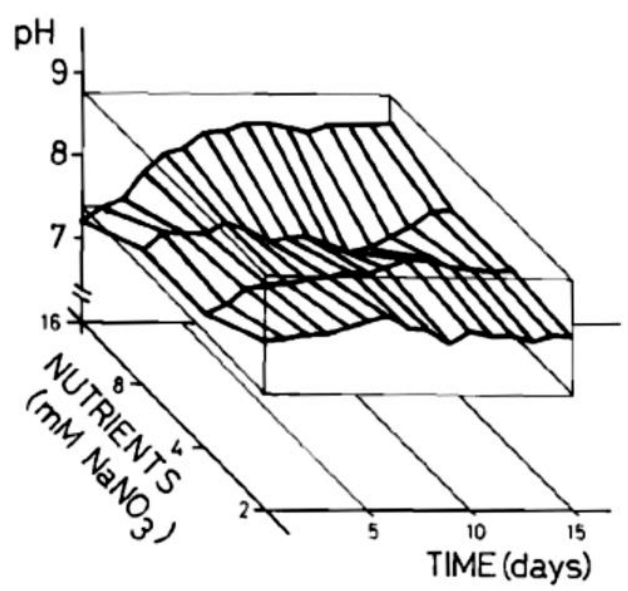

Fig. 1. $\mathrm{pH}$ values in mass cultures of $T$. suecica at different nutrient concentrations.

Carbon supply and sufficient light intensity are the two important factors for the production of mass cultures of microalgae with high cellular densities. The growth kinetics model (cells $/ \mathrm{ml})$ of the mass culture of $T$. suecica was similar to one of batch culture (Fabregas et al., 1984a). In algal batch experiments, with both limited volume and supply of nutrients, a logistic curve is usually observed (Schantz and Zahler, 1981).

We plotted cellular density, protein $(\mu \mathrm{g} / \mathrm{ml})$, chlorophyll $\alpha(\mu \mathrm{g} / \mathrm{ml})$ and carbohydrates $(\mu \mathrm{g} / \mathrm{ml})$ against time for each nutrient concentration, obtaining three-dimensional figures (Figs. 2, 3, $4,5)$. Statistical treatment of these figures is presented in Table 1. From the equations calculated, we can establish the growth kinetics for each culture and predict the growth of the microalgal population. The values of $a, b, c, d$ and $e$ are presented in Table 3 . From this equation we calculated doublings/day or the inverse of the duplication time $\left(\mathrm{t}_{d}{ }^{-1}\right)$. The initial time $\left(t_{i}\right)$ and final time $\left(t_{n}\right)$ of the logarithmic phase were established for each nutrient concentration (Table 1). 
Statistical analysis of the cellular content of $T$. suecica grown at different nutrient concentrations in mass culture

\begin{tabular}{|c|c|c|c|c|c|c|c|c|c|c|}
\hline \multirow[t]{2}{*}{$\cdot$} & \multirow[t]{2}{*}{ Growth phase } & \multirow[t]{2}{*}{$P$} & \multicolumn{8}{|c|}{ Nutrient concentration ${ }^{a}$} \\
\hline & & & $2 \mathrm{mM}$ & & & $4 \mathrm{mM}$ & & $8 \mathrm{mM}$ & & $16 \mathrm{mM}$ \\
\hline $\begin{array}{l}\text { Protein/cell } \\
(\mathrm{pg})\end{array}$ & $\begin{array}{l}\text { Stationary }{ }^{b} \\
\text { Logarithmic }^{c}\end{array}$ & $\begin{array}{l}0.01 \\
0.01\end{array}$ & $\begin{array}{r}41.77 \pm \\
* 52.20 \pm\end{array}$ & $\begin{array}{c}3.28 \\
14.20^{d}\end{array}$ & $\begin{array}{l}< \\
=\end{array}$ & $\begin{array}{l}59.83 \pm 7.88 \\
39.84 \pm 11.65\end{array}$ & $\begin{array}{l}> \\
=\end{array}$ & $\begin{array}{l}32.50 \pm 1.31 \\
31.33 \pm 7.28^{\mathrm{e}}\end{array}$ & $\begin{array}{l}> \\
=\end{array}$ & $\begin{array}{l}27.75 \pm 1.89 \\
29.20 \pm 1.92^{\mathrm{e}}\end{array}$ \\
\hline Chlorophyll $a /$ cell & Stationary & 0.01 & $2.03 \pm$ & 0.32 & $<$ & $3.80 \pm 0.45$ & $=$ & $3.10 \pm 0.32$ & $=$ & $3.19 \pm 0.33$ \\
\hline (pg) & Logarithmic & 0.01 & $* * 2.15 \pm$ & $0.58^{f}$ & $=$ & $3.01 \pm 0.40$ & $=$ & $3.20 \pm 0.43^{\mathrm{g}}$ & $=$ & $3.74 \pm 0.56^{\mathrm{g}}$ \\
\hline Carbohydrates/cell & Stationary & 0.01 & $26.43 \pm$ & 1.86 & $=$ & $21.78 \pm 3.36$ & $=$ & $27.82 \pm 2.05$ & $=$ & $24.78 \pm 2.13$ \\
\hline (pg) & Logarithmic & 0.01 & $27.98 \pm$ & 5.77 & $=$ & $28.68 \pm 5.40$ & $=$ & $24.70 \pm 6.96$ & $=$ & $19.84 \pm 3.80$ \\
\hline RNA/cell & Stationary & 0.01 & $2.77 \pm$ & 1.66 & $<$ & $4.95 \pm 0.91$ & $=$ & $5.48 \pm 1.05$ & $=$ & $4.17 \pm 0.25$ \\
\hline (pg) & Logarithmic & 0.01 & $6.98 \pm$ & 0.09 & $=$ & $7.15 \pm 0.22$ & $>$ & $5.99 \pm 0.16$ & $>$ & $3.78+1.19$ \\
\hline DNA/cell & Stationary & 0.01 & $0.13 \pm$ & 0.08 & $=$ & $0.15 \pm 0.09$ & $=$ & $0.10 \pm 0.03$ & $=$ & $0.25 \pm 0.18$ \\
\hline & Logarithmic & 0.01 & $1.09 \pm$ & 0.68 & $=$ & $0.11 \pm 0.02$ & $=$ & $0.12 \pm 0.06$ & $=$ & $0.21 \pm 0.25$ \\
\hline \multirow[t]{2}{*}{ Protein/carbohydrate } & Stationary & & 1.58 & & & 2.74 & & 1.20 & & 1.12 \\
\hline & Logarithmic & & 1.87 & & & 1.39 & & 1.27 & & 1.47 \\
\hline \multirow[t]{2}{*}{ Protein/chlorophyll $a$} & Stationary & & 20.58 & & & 15.74 & & 10.48 & & 8.7 \\
\hline & Logarithmic & & 24.28 & & & 13.23 & & 9.8 & & 7.8 \\
\hline \multirow[t]{2}{*}{ Protein/RNA } & Stationary & & 15.08 & & & 12.08 & & 5.93 & & 6.65 \\
\hline & Logarithmic & & 7.48 & & & 5.57 & & 5.23 & & 7.72 \\
\hline \multirow[t]{2}{*}{ DNA/RNA } & Stationary & & 0.05 & & & 0.03 & & 0.02 & & 0.06 \\
\hline & Logarithmic & & 0.16 & & & 0.01 & & 0.02 & & 0.06 \\
\hline
\end{tabular}

\footnotetext{
${ }^{\text {a Expressed as }} \mathrm{NaNO}_{3}$ concentration.

${ }^{b}$ One-way analysis of variance (ANOVA).

${ }^{c}$ One-way analysis of covariance (ANCOVA).

$* \mathrm{~d}>\mathrm{e}, P<0.01$.
}

$* *_{\mathrm{f}}<\mathrm{g}, P<0.01$.

TABLE 3

Values of the coefficients $a, b, c, d$ and $e$ of the equation $f(t)=a+b t+c t^{2}+d t^{3}+e t^{4}$ calculated by a multiple non-linear least squares: regression. (A) cells $/ \mathrm{ml}$; (B) protein $/ \mathrm{ml}$; (C) chlorophyll $a / \mathrm{ml} ;$ (D) carbohydrates $/ \mathrm{ml}$

\begin{tabular}{llclr}
\hline A & \multicolumn{4}{l}{ Nutrient concentration } \\
\cline { 2 - 5 } & $2 \mathrm{mM}$ & $4 \mathrm{mM}$ & $8 \mathrm{mM}$ & $16 \mathrm{mM}$ \\
\hline$a$ & +59.5875 & +37.0820 & +44.6376 & +71.5005 \\
$b$ & -52.5082 & -7.6925 & -1.0054 & -110.5700 \\
$c$ & +24.6674 & +10.2548 & +9.0626 & +62.8148 \\
$d$ & -1.1259 & -0.2567 & +0.0461 & -6.6173 \\
$e$ & -0.0402 & -0.0223 & -0.0294 & +0.2103 \\
SD & 34.51 & 40.51 & 38.03 & 43.30 \\
\hline $\mathrm{C}$ & \multicolumn{5}{c}{ Nutrient concentration } & & \\
\cline { 2 - 5 } & $2 \mathrm{mM}$ & $4 \mathrm{mM}$ & $8 \mathrm{mM}$ & $16 \mathrm{mM}$ \\
\hline$a$ & +0.1775 & +1.1252 & +3.6189 & +3.9864 \\
$b$ & +0.2025 & +1.1285 & +1.1793 & -2.9632 \\
$c$ & +0.1059 & -0.1335 & -0.1304 & +2.4333 \\
$d$ & +0.0235 & +0.0543 & +0.0351 & -0.3131 \\
$e$ & -0.0027 & -0.0033 & -0.0018 & +0.0117 \\
SD & 0.67 & 1.83 & 1.18 & 2.03
\end{tabular}

\begin{tabular}{lcccc}
\hline B & \multicolumn{4}{l}{ Nutrient concentration } \\
\cline { 2 - 5 } & $2 \mathrm{mM}$ & $4 \mathrm{mM}$ & $8 \mathrm{mM}$ & $16 \mathrm{mM}$ \\
\hline$a$ & +26.0839 & +21.4348 & +27.9490 & +15.1608 \\
$b$ & -2.5189 & -66.6777 & -9.0007 & -15.6242 \\
$c$ & +4.0207 & +38.2386 & +6.9192 & +19.2188 \\
$d$ & +0.1342 & -4.2563 & -0.3717 & -2.5659 \\
$e$ & -0.0347 & +0.1398 & -0.0003 & +0.0970 \\
SD & 14.33 & 23.39 & 17.03 & 11.60 \\
\hline $\mathrm{D}$ & Nutrient concentration & & \\
\cline { 2 - 5 } & $2 \mathrm{mM}$ & $4 \mathrm{mM}$ & $8 \mathrm{mM}$ & $16 \mathrm{mM}$ \\
\hline$a$ & +22.7203 & +19.7111 & +19.1450 & +13.8951 \\
$b$ & -33.2628 & -13.7921 & -1.4554 & -4.9147 \\
$c$ & +24.5309 & +9.7264 & +9.2451 & +5.7753 \\
$d$ & -3.8042 & -1.1238 & -1.0240 & -0.2170 \\
$e$ & +0.1818 & +0.0377 & +0.0306 & -0.0143 \\
SD & 8.08 & 7.71 & 14.92 & 15.72
\end{tabular}.

The growth and biochemical composition of $T$. suecica were evaluated in the nutrient concentration range of 2, 4, 8 and $16 \mathrm{mM}$ of $\mathrm{NaNO}_{3}$, and salinity of $35 \%$. These conditions had been demonstrated previously to be optimum for T. suecica, in batch cultures (Fabregas et al., 1984a).

After a lag phase of 1-2 days, the cells entered exponential growth, which lasted 2-6 days. Optimal nutrient concentrations to produce a maximum cellular density were 8 and $16 \mathrm{mM}$ of $\mathrm{NaNO}_{3}$, which gave $7.83 \times 10^{6}$ and $7.15 \times 10^{6}$ cells/ml respectively (Fig. 2). Statistically, there are no significant differences between these two cellular densities $(P<0.01)$. Cellular densities of $4.76 \times 10^{6}$ and $5.11 \times 10^{6}$ cells $/ \mathrm{ml}$ were obtained with nutrient concentrations of 2 and $4 \mathrm{mM}$ respectively. These densities are also statistically equal $(P<0.01)$. A nutrient 
concentration of $2 \mathrm{mM}$ of $\mathrm{NaNO}_{3}$ is commonly used (McLachlan, 1964). In Table 3A the values of the growth-predicting parameters are presented.

The maximum growth velocity of $T$ suecica cultures in the logarithmic phase was between 0.53 and 0.63 doublings/day for 2 to $8 \mathrm{mM} \mathrm{NaNO}_{3}$. These results are similar to those obtained in batch cultures (Fabregas et al., 1984a). In the culture with $16 \mathrm{mM}$ of $\mathrm{NaNO}_{3}$ the maximum growth velocity reached 0.98 doublings/day (Table 1 ).

Cellular volume of $T$. suecica increased with nutrient concentration from 252.9 to $905.4 \mu^{3}$ with $P<0.05$. The increase in the cellular volume appears not to have been produced by the increase in salinity of the culture medium, since maximum nutrient concentration (16 mM of $\mathrm{NaNO}_{3}$ ) produced an increase in the salinity only from $35 \%$ o to $36.4 \%$. The vari ability is also light-independent, since the same cellular densities presented different cellular volumes. In other microalgae, such as Dunaliella bioculata, cell volume was also light-independent in a hypersaline medium (Grizeau et al., 1983). It may be that $T$. suecica has a volume-regulating mechanism in relation to the composition and concentration of the culture medium. In the present case, cellular volume was not affected by the carbon source, although the main effect of a limitation of inorganic carbon appears to be on cell size rather than on the chemical structure of the biomass (Goldman and Graham, 1981); but in our culture conditions carbon supply was always in excess and was never limiting.
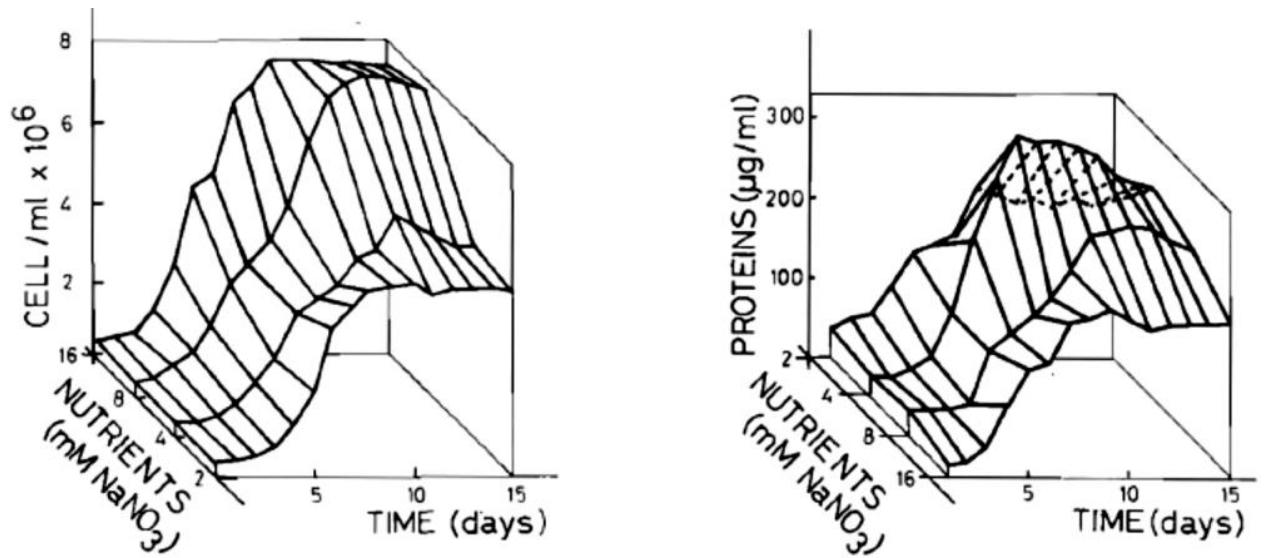

Fig. 2. Growth of T. suecica at different nutrient concentrations, expressed as $\mathrm{NaNO}_{3}$ concentrations.

Fig. 3. Protein concentration in mass cultures of $T$. suecica at different nutrient concentrations.

At the end of the culture period (15 days) the protein content had reached maximum values of $306 \mu \mathrm{g} / \mathrm{ml}$ and $59.8 \mu \mathrm{g} / \mathrm{cell}$ (Tables 1 and 2) with a nutrient concentration of $4 \mathrm{mM}$ of $\mathrm{NaNO}_{3}$, decreasing to $46 \%$ with higher concentrations. These differences in the protein content were more acute than those found in Dunaliella salina grown in different culture media, nitrate or glutamine, with a $12 \%$ higher protein content (Kosmakova and 
Prozumenshchikova, 1983). During the logarithmic phase, protein was regulated by the nutrient concentration. Great differences in the protein/cell content such as those shown here can seriously affect the success of a culture of mollusc larvae.
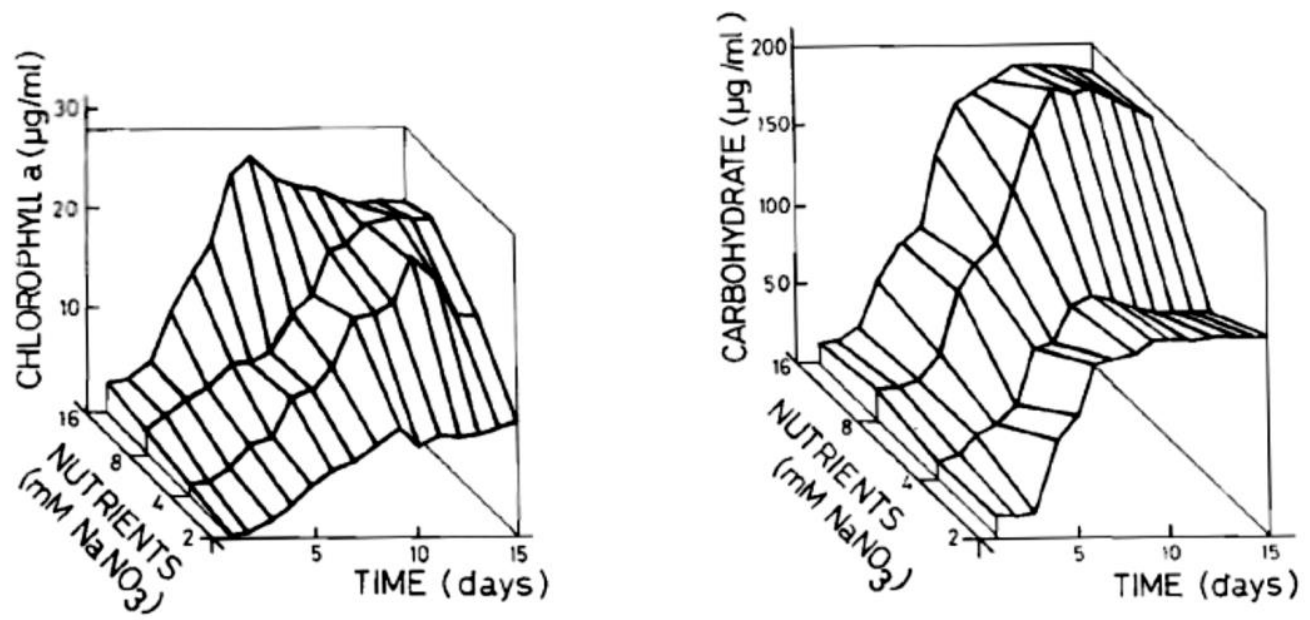

Fig. 4. Chlorophyll $a$ concentration in mass cultures of $T$. suecica at different nutrient concentrations.

Fig. 5. Carbohydrates concentration in mass cultures of $T$. suecica at different nutrient concentrations.

The protein/carbohydrate ratio ranged between 1.12 and 2.74 in the stationary phase and between 1.39 and 1.87 in the logarithmic phase (Table 2). These ratios are similar to those found fot other microalgae (between 0.23 and 2.0, Parsons et al., 1961), for Skeletonema costatum (from 0.5 to 2.0 over a diel cycle, Hitchcock, 1980) and for nine diatom species, where there was a decline from 2.0 to between 0.1 and 0.5 as nitrogen was depleted (Myklestad, 1974). These ratios are lower than the ratio of 1.58 for $T$. suecica obtained with a nutrient concentration of $2 \mathrm{mM}$ of $\mathrm{NaNO}_{3}$. This represented an efficiency of $100 \%$ and, therefore, the nitrogen was depleted.

The efficiency of nitrogen transformation decreased as the nutrient concentration increased. We established this efficiency as the ratio between the nitrogen added in nitrate form to the culture medium and the protein nitrogen produced per culture. A maximum efficiency of $108 \%$ was reached with $2 \mathrm{mM}$ of $\mathrm{NaNO}_{3}$. A value greater than $100 \%$ can be due to residual nitrogen, present in the seawater used in the preparation of the culture medium and to the possible increase in the availability of such nitrogen after the sea water has been autoclaved. An efficiency of $100 \%$ means that all the inorganic nitrogen in the culture medium has been absorbed by the cells. Nutrient concentrations of 8 and $16 \mathrm{mM}$, which produced the maximum biomass, had the least efficiency at $27.5 \%$ and $14 \%$ respectively. These data indicate that the cheapest production is obtained with a nutrient concentration of $2 \mathrm{mM}$ of $\mathrm{NaNO}_{3}$ (Fig. 6). 


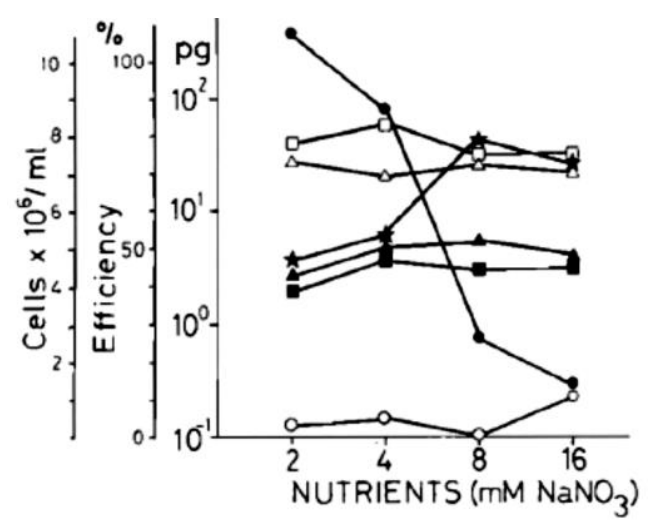

Fig. 6. Cellular density and chemical composition of $T$. suecica in the stationary phase, at different nutrient concentrations. $(\star)$ cells/ml; (ㄷ) protein/cell; $(\Delta)$ carbohydrates/

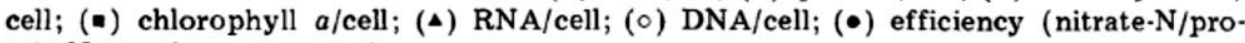
tein-N transformation rate).

Protein/chlorophyll $\alpha$ ratios ranged between 20.58 and 8.7 in the stationary phase and between 24.28 and 7.8 in the logarithmic phase. This ratio decreased similarly in both growth phases as the nutrient concentration increased.

In the logarithmic phase, protein/cell and chlorophyll $\alpha /$ cell appeared to be inversely related. The cellular concentrations of each compound were not related to nitrogen depletion in these cultural conditions.

The protein/RNA ratio was practically constant during the logarithmic phase and decreased at a concentration of $8 \mathrm{mM}$ of $\mathrm{NaNO}_{3}$ in the stationary phase.

Chlorophyll $\mathrm{a} / \mathrm{ml}$ and chlorophyll $\alpha /$ cell were constant in the stationary phase for 4,8 and 16 $\mathrm{mM}$ of $\mathrm{NaNO}_{3}$; chlorophyll $\alpha /$ cell reached values be ween 3.1 and $3.8 \mathrm{pg} / \mathrm{cell}$. These values are significantly higher than the $2.03 \mathrm{pg} / \mathrm{cell}$ obtained with $2 \mathrm{mM}$ of $\mathrm{NaNO}_{3}$. Changes in chlorophyll alevels were related to the nitrogen depletion which occurred in the stationary phase in the cultures with $2 \mathrm{mM}$ of $\mathrm{NaNO}_{3}$. Large changes in chlorophyll levels have also been found under nitrate and ammonia limitations Caperon and Meyer, 1972\}. This suggests an adaptative mechanism to increase the chlorophyll to a level of 3.1 and $3.8 \mathrm{pg} / \mathrm{cell}$ at the saturation level of nitrogen in the culture, whereas higher concentrations do not increase this value.

There was a relationship between nutrient concentration and chlorophyll $\alpha / c e l l$ in the logarithmic phase, with an increase from $2.15 \mathrm{pg} / \mathrm{cell}$ to $3.74 \mathrm{pg} / \mathrm{cell}$. Similar results have been obtained (Falkowski and Stone, 1975) for fluctuations in chlorophyll $\alpha$ with nitrogen, suggesting an adaptative mechanism which involves increases in photosynthesis resulting from increased nitrogen-mediated chlorophyll a concentration. As the chlorophyll $\alpha / c e l l$ content in the stationary phase was constant, it is clear that there was no light-limitation due to a shading of the cells in the conditions of high cellular density. 
Carbohydrate/cell was constant in both the logarithmic and the stationary phases and though it was not related to nitrogen depletion, others have related it to light and temperature (Hitchcock, 1980).

RNA concentrations ranged from 4.17 to $5.48 \mathrm{pg} / \mathrm{cell}$ with 4.8 and $16 \mathrm{mM}$ of $\mathrm{NaNO}_{3}$, whereas the culture with $2 \mathrm{mM}$ of $\mathrm{NaNO}_{3}$ produced a significantly lower concentration (2.77 $\mathrm{pg} / \mathrm{cell})$. There could be a cellular mechanism which decreases the concentration of RNA/cell when nitrogen is depleted and which maintains the RNA/cell constant, and independent of the different nutrient concentrations, when nitrogen is at the saturation level in the stationary phase. In the logarithmic growth phase, RNA/cell values were similar in the 2 and $4 \mathrm{mM}$ $\mathrm{NaNO}_{3}$ nutrient concentrations with levels of 6.98-7.15 pg/cell, and these values were higher than those of the cultures with 8 and $16 \mathrm{mM}$ of $\mathrm{NaNO}_{3} . \mathrm{RNA} /$ cell decreased as the nutrient concentration increased; it was directly related to protein and chlorophyll $\alpha$ and inversely related to cellular density. However, there was no obvious relationship between RNA and doublings/day since the maximum doublings/day value of 0.98 corresponded to the minimum $\mathrm{RNA} /$ cell concentration. Therefore, we cannot relate the growth velocity of the culture to the RNA/cell concentration in the present conditions, although in other systems the RNA has been said to serve as a measure of active biomass (Koliander et al., 1984).

The concentration of DNA/cell was constant in all of the nutrient concentrations assayed and in both growth phases; DNA/cell was, therefore, not related to doublings/day. These data are in general accordance with those of other authors who have found that the rate of DNA synthesis is independent of division rate (Martin and Gonzalez, 1978).

The DNA content of $T$. suecica cells ranged from 0.1 to $1.09 \mathrm{pg} / \mathrm{cell}$. These values are similar to those in other, smaller, marine micro algae such as Monochrysis lutheri and Navicula pelliculosa which contain approximately $0.1 \mathrm{pg}$ of DNA per cell (Holm-Hansen, 1969). There was no proportionality between DNA/cell and the increase in cellular volume during the stationary phase, under the cultural conditions described above.

A correlation has been shown between the rates of RNA, DNA and protein synthesis, and the rate of cell growth (Nierlich, 1978; Pritchard et al., 1969; Leick, 1968). But such a correlation was not observed here for the DNA/RNA ratio and this is due to the great standard deviation in the DNA/cell measurements. Perhaps the method we used for estimating DNA in this marine microalga was not the most suitable, and more accurate measurements might be o.btained by using another method (Karl, 1981).

Great variability in the chemical composition of $T$. suecica has been shown to result from environmental conditions. Variations in the chemical composition of $T$. suecica, grown in mass culture, are closely related to changes in nutrient concentrations; such variations occur 
in protein, chlorophyll a and RNA content, showing differences of $215 \%, 190 \%$ and $203 \%$, respectively, in the stationary phase. It seems reasonable to suggest that variability in the protein content per cell is a most important factor in the use of $T$. suecica for animal feeding in aquaculture systems. Differences between 27.7 and $59.8 \mathrm{pg}$ of protein/cell, in the stationary phase (Table 2), are equivalent to a $215 \%$ deviation in the protein content due solely to the nutrient concentration, and any system of mariculture where microalgae are used as feed would be severely affected by such variations. It has already been reported elsewhere that variations in the chemical composition of microalgae are linked to changes in nutrient concentration (Myklestad and Haug, 1972), to salinity and nutrient concentration (Fabregas et al., 1984a) and to growth rate (Goldman et al., 1979; Rhee, 1980), and also that the calorific value of the cells varies with changes in specific growth rate (Scott, 1980).

\section{Acknowledgements}

Thanks are due to Prof. Dr. B. Regueiro Varela for his interesting comments, to Prof. Dr. C. Ferreiros for excellent help in statistical analysis and to Prof. Dr. B. Regueiro Garcia for allowing us access to computational facilities.

This work was supported by a grant of Dirección General de Ordenación Pesquera, Madrid, Spain. Part of this work was supported by a grant to C.H. from Fundación Juan March, Madrid, Spain.

\section{References}

1. Bayne BL. The biology of mussel larvae. Marine Mussels: Their Ecology and Physiology 1976:81-120.

2. Bradford MM. A rapid and sensitive method for the quantitation of microgram quantities of protein utilizing the principle of protein-dye binding. Anal Biochem 1976;72(1-2):248-54.

3. Brewer PG, Goldman JC. Alkalinity changes generated by phytoplankton growth. Limnol Oceanogr 1976;21(1):108-17.

4. Caperon J, Meyer J. Nitrogen-limited growth of marine phytoplankton-I. changes in population characteristics with steady-state growth rate. Deep-Sea Research and Oceanographic Abstracts 1972;19(9):601-18.

5. Fabregas J, Abalde J, Herrero C, Cabezas B, Veiga M. Growth of the marine microalga tetraselmis suecica in batch cultures with different salinities and nutrient concentrations. Aquaculture 1984;42(3-4):207-15. 
6. Fabregas J, Herrero C, Veiga M. Effect of oil and dispersant on growth and chlorophyll $\alpha$ content of the marine microalga tetraselmis suecica. Appl Environ Microbiol $1984 ; 47(2): 445-7$.

7. Falkowski PG, Stone DP. Nitrate uptake in marine phytoplankton: Energy sources and the interaction with carbon fixation. Mar Biol 1975;32(1):77-84.

8. Goldman JC. Outdoor algal mass cultures. I. applications. Water Res 1979;13(1):1-19.

9. Goldman JC, Graham SJ. Inorganic carbon limitation and chemical composition of two freshwater green microalgae. Appl Environ Microbiol 1981;41(1):60-70.

10. Goldman JC, McCarthy JJ, Peavey DG. Growth rate influence on the chemical composition of phytoplankton in oceanic waters. Nature 1979;279(5710):210-5.

11. Goldman JC, Porcella DB, Joe Middlebrooks E, Toerien DF. The effect of carbon on algal growth-its relationship to eutrophication. Water Res 1972;6(6):637-79.

12. Grizeau D, Jeanne N, Puiseux-Dao S. Effects of various factors and inhibitors on the regulation of cell volume in dunaliella bioculata. Plant Science Letters 1983;28:213-22.

13. Hitchcock GL. Diel variation in chlorophyll $\alpha$, carbohydrate and protein content of the marine diatom skeletonema costatum. Mar Biol 1980;57(4):271-8.

14. Holm-Hansen O. Algae: Amounts of DNA and organic carbon in single cells. Science 1969;163(3862):87-8.

15. Karl DM. Simultaneous rates of ribonucleic acid and deoxyribonucleic acid syntheses for estimating growth and cell division of aquatic microbial communities. Appl Environ Microbiol 1981;42(5):802-10.

16. Kharatyan SG. Microbes as food for humans. Annu Rev Microbiol 1978;32:301-27.

17. Kochert G. Carbohydrate determination by the phenol-sulfuric acid method. Handbook of Phycological Methods.Physiological and Biochemical Methods 1978:95-7.

18. Kochert G. Quantitation of the macromolecular components of microalgae. Handbook of Phycological Methods.Physiological and Biochemical Methods 1978:189-95.

19. Koliander B, Hampel W, Roehr M. Indirect estimation of biomass by rapid ribonucleic acid determination. Appl Microbiol Biotechnol 1984;19(4):272-6. 
20. Kosmakova V, Prozumenshahicova L. Growth and biochemical composition of the algae dunaliella salina and platymonas viridis fed on organic and inorganic nitrogen. Biol.Morya. 1983;1:42-6.

21. Laing I, Helm MM. Factors affecting the semi-continuous production of tetraselmis suecica (kylin) butch. in 200-I vessels. Aquaculture 1981;22(C):137-48.

22. Laing I, Utting S. The influence of salinity on the production of two commercially important unicellular marine algae. Aquaculture 1980;21:79-86.

23. Leick V. Ratios between contents of DNA, RNA and protein in different micro-organisms as a function of maximal growth rate. Nature 1968;217(5134):1153-5.

24. Martin DF, Gonzalez MH. Effects of salinity on synthesis of DNA, acidic polysaccharide, and growth in the blue-green alga, gomphosphaeria aponina. Water Res 1978;12(11):951-5.

25. Mclachlan J. Some considerations of the growth of marine algae in artificial media. Can J Microbiol 1964;10:769-82.

26. Myklestad S. Production of carbohydrates by marine planktonic diatoms. I. comparison of nine different species in culture. J Exp Mar Biol Ecol 1974;15(3):261-74.

27. Myklestad S, Haug A. Production of carbohydrates by the marine diatom chaetoceros affinis var. willei (gran) hustedt. I. effect of the concentration of nutrients in the culture medium. J Exp Mar Biol Ecol 1972;9(2):125-36.

28. Nierlich DP. Regulation of bacterial growth, RNA, and protein synthesis. Annu Rev Microbiol 1978;32:393-432.

29. Parsons TR, Strickland JDH. Particulate organic matter. III.I. pigment analysis. III.I.I. determination of phytoplankton pigments. J.Fish.Res.Board can. 1965;18:117-27.

30. Parsons T, Stephens K, Strickland J. On the chemical composition of eleven species of phytoplankton. J.Fish.Res.Board can. 1961;18:101-16.

31. Pritchard R, Barth $P$, Collins J. Control of DNA synthesis in bacteria. Symp.Soc.Gen.Microbiol. 1969;19:263-97.

32. Rhee GY. Continuous culture in phytoplankton ecology. Advances in Aquatic Microbiology;2:151-203. 
33. Schanz F, Zahler U. Prediction of algal growth in batch cultures. Schweizerische Zeitschrift Für Hydrologie 1981;43(1):103-13.

34. Scott JM. Effect of growth rate of the food alga on the growth/ingestion efficiency of a marine herbivore. J Mar Biol Assoc U K 1980;60:681-702.

35. Walne PR. Culture of Bivalve Molluscs 1974. 